\title{
Integration of Energy and Fire Prevention Systems in Green Building
}

\author{
Sergio Eduardo Palmiere, Carmen Elena Martinez Riascos and Luis Alberto Martinez Riascos \\ CECS (Engineering and Social Science Center), UFABC (Federal University of ABC), Santo Andre, SP 09210-580, Brazil
}

Received: June 18, 2015 / Accepted: July 10, 2015 / Published: September 30, 2015.

\begin{abstract}
Green buildings should be sustainable, efficient, economical, and to improve the quality of life of users and nearby residents. Unfortunately, some architecture features fostered by energy and environmental certifications do not comply with fire prevention codes. Several factors can influence a building's energy efficiency and fire safety, such as bigger or smaller glass areas, building material thermal inertia, and the use of sustainable solutions such as green roofs. In this work, a methodology for integrating energy efficiency and fire prevention in green buildings is presented. A case study comparing a full glass skin and a building with $40 \%$ window size is considered. Also, the methodology permits modifications for obtaining a safe and energy efficient building.
\end{abstract}

Key words: Energy efficiency in buildings, fire prevention, EnergyPlus, Pyrosim, pathfinder.

\section{Introduction}

Commercial and residential buildings are some of the largest energy consumers, accounting for 30\%-40\% of all primary energy consumed in developed countries [1]. Most of this energy is consumed by the cooling or internal heating systems, and on a smaller scale to supply lighting and security systems. For the commercial sector, the air conditioning system represents $48 \%$ of all final consumption, lighting $24 \%$, building control equipment $15 \%$, elevators and other loads $13 \%$. Buildings with appropriate planning and best orientation can reduce energy consumption by up to $30 \%$, when compared to other buildings, that offer similar comfort levels without an energy aware design. An increase as little as $2 \%$ on the initial investment of a building - construction costs - could save up to $20 \%$ of its operational costs over its entire life cycle [2]. A building design should ensure sustainability, comfort, quality of life and energy efficiency to residents. Given these needs aroused the concept of green buildings.

Corresponding author: Luis Alberto Martinez Riascos, professor, research fields: fuel cell and control systems. E-mail: luis.riascos@ufabc.edu.br.
LEED (leadership in energy and environmental design) is a building certification provided by a non-governmental, non-profit organization, USGBC (U.S. Green Building Council). LEED provides volunteer and market-oriented rating systems based on energy efficiency and environmental standards [3-5]. Unfortunately, some architecture features fostered by LEED do not comply with fire prevention codes [6-8]. Amongst the most dangerous features are internal voids, which eliminate the compartmentalization protection, double skin facades, excessive natural ventilation, and the choice of low thermal insulation construction materials without fireproof treatment. In order to achieve maximum energy efficiency with proper fire safety, the buildings must be designed to integrate the existing standards and fire prevention codes [9]. Small modifications of the building envelope can save cooling system energy, reducing the possibility and severity of fire damage. The main objective of this work is to propose a methodology to integrate fire prevention with LEED standard requirements, ensuring the HVAC (heating, ventilation and air conditioning) system maximum efficiency and maintaining fire safety. A case study applying the São Paulo Fire State 
code in Brazil is introduced [10], however, any fire code could be applied with the proposed methodology. This paper is organized as follows: Section 2 discusses some building energy efficiency and fire protection issues; Section 3 presents a methodology for integrating energy efficiency and fire safety applied to a case study; Section 4 analyzes the results. Finally, conclusions are stated.

\section{Building Energy Efficiency and Fire Protection Issues}

Green buildings are designed to be sustainable, efficient and architecturally attractive. Many of the applied techniques to integrate sustainability and energy efficiency can increase fire risks. For example, the use of green roofs can increase the building energy efficiency but also increase the fire risk by providing more fuel. The integration of energy efficiency and fire safety maintaining the desired sustainability requires that appropriate studies be conducted. Among the main factors, that directly affect the building energy efficiency and its fire risks are included:

- building architectural design;

- specific surface of building materials;

- characteristics of building construction materials;

- amount and distribution of combustible materials;

- fire starting place;

- openings between interior spaces allowing fire spread;

- weather conditions such as temperature and relative humidity;

- architectural design of surrounding areas;

- energy control and fire prevention systems.

\section{Methodology for Energy Efficiency and Fire Safety}

For energy efficiency simulation, the following programs were used: Google Sketch UP 8 was used to model the building envelope and EnergyPlus 7-2 was used to perform energy simulations. EnergyPlus is a free open source simulation program created by DOE
(Department of Energy, USA) for modeling buildings and their heating, ventilation and air conditioning equipment. It is indicated for energy simulations by ASHRAE (American Society of Heating, Refrigerating and Air-Conditioning Engineers) Standard 90-1-2010 [11], however, since EnergyPlus is a rendering engine and does not have a friendly graphical interface, Open Studio 0.11.0, which presents a graphical interface facilitating the data integration and visualization, was also used.

Fire simulation was conducted in Pyrosim, version 2012 [12]. The program provides a GUI (graphic user interface) for applying the FDS (fire dynamics simulator) + evacuation, developed by NIST (National Institute of Standard. and Technology), and simulate fire scenarios applying CFD (computational fluid dynamics). Pyrosim has a limited combustive material data library, but facilitates the visualization, simulation and use of FDS simulator, also it is applied to simulate building ventilation according to the building envelope. Evacuation simulation was performed in Pathfinder [13], which permits to analyze different scenarios.

For considering the integration of energy efficiency in green buildings in view of fire safety standards, a commercial building was analyzed, comparing two envelope options: a fully glass skin and an opaque skin with $40 \%$ window size. For simplification, simulations were performed considering these options as two different buildings. The analyses of the two buildings followed the methodology presented below.

\subsection{Pre-project}

The building contains 11 floors (ground floor plus 10 elevated floors), they are $8.5 \mathrm{~m}$ wide by $25.5 \mathrm{~m}$ long. Each floor is $2.7 \mathrm{~m}$ high with external walls $25 \mathrm{~cm}$ thick and internal walls $15 \mathrm{~cm}$ thick. The elevated floors consist in two rooms per floor with building access through an emergency stairwell and an elevator, except for the ground floor, which contains only one room. Fig. 1 shows the elevated floor building plan. 


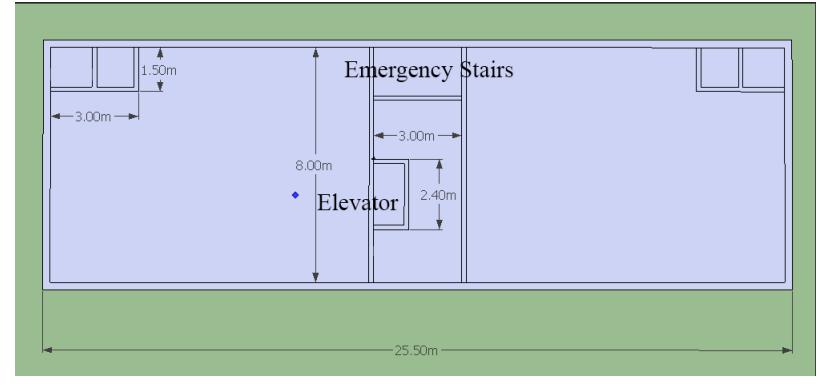

Fig. 1 Elevated floor building plan.

\subsection{Building's Population}

The population determines what types of combustive material will be incorporated to the building, and the psychology and physical aptitude of the users, if it helps or delays evacuation. This building was designed to attend an average fixed population of 120 people (medics, psychologists, lawyers, engineers, etc.), and a floating population of 150 people (clients). The physical and psychological conditions of the building population are defined as average.

\subsection{Building Location}

The correct building location determines the weather file to be used with EnergyPlus. The geo localization considers the influences of the local climate, solar radiation and temperature. The building was geo locate with the Google Earth tool program integrated with Google Sketch UP 8, latitude: -23.671470S, longitude: $-46.552697 \mathrm{~W}$, time zone: -3 and elevation: 803 m, São Paulo, Brazil. Sketch Up also helps to simulate shadow generated by nearby buildings.

\subsection{Fire Code}

In this case, the São Paulo Fire Code, Decree 56819 was applied. Brazil has different and outdated fire codes in some cities and states. Decree 56819 applies tables using the building height to determine the fire loads and fire protections required by law. The building has $29.7 \mathrm{~m}$ high and $700 \mathrm{MJ} / \mathrm{m}^{2}$ fire load, demanding $90 \mathrm{~min}$ of passive fire resistance time for all construction materials, 25 tons. Firefighter vehicle access, structural fire safety, horizontal and vertical compartmentalization, finishing and construction materials control, emergency exits, building emergency response team, emergency light, fire alarms, emergency signaling, fire extinguishers, and fire hydrants.

\subsection{Building Materials}

The fifth step consists of determining the building material sets and construction layer. EnergyPlus uses this information to determine the building energy consumption. Table 1 presents two common construction material sets that should be recycled, have low environmental impact, and can be extracted near the construction site.

\subsection{Energy Consumption Analysis}

The energy consumption information gathers the quantity and the use of the HVACs. Eleven thermal zones were considered, one for each floor. Those zones represent areas where thermal difference can exist and are close enough to interact with each other. The HVAC systems have VAV (variable air volume) with PFP (parallel fan powered) boxes and reheat. The building internal loads represent the energy released as heat by people ( 0.3 radiant fraction), lamps $\left(6.4 \mathrm{~W} / \mathrm{m}^{2}\right)$, and electrical equipment $\left(9.7 \mathrm{~W} / \mathrm{m}^{2}\right)$. The infiltration represents the airflow that penetrates into unintended areas of the thermal environment, usually caused by opening and closing doors and windows.

Table 1 Construction material lists applied in the simulation.

\begin{tabular}{|c|c|c|}
\hline Elements & List 1 & List 2 \\
\hline Roof & Heavy concrete & $\begin{array}{l}\text { Exterior tile } \\
\text { Heavy concrete }\end{array}$ \\
\hline Interior slab & $\begin{array}{l}\text { Tile } \\
\text { Light concrete } \\
\text { Air interlayer } \\
\text { Plaster } \\
\end{array}$ & $\begin{array}{l}\text { Ceramic floor } \\
\text { Mortar plastering } \\
\text { Light concrete }\end{array}$ \\
\hline Interior wall & $\begin{array}{l}\text { Mortar plastering } \\
\text { Brick }(25 \mathrm{~cm})\end{array}$ & $\begin{array}{l}\text { Mortar plastering } \\
\text { Ceramic brick }\end{array}$ \\
\hline Exterior wall & $\begin{array}{l}\text { Granite } \\
\text { Mortar plastering } \\
\text { Light concrete } \\
\text { Mortar plastering }\end{array}$ & $\begin{array}{l}\text { Mortar plastering } \\
\text { Ceramic brick }\end{array}$ \\
\hline Floor & Heavy concrete & $\begin{array}{l}\text { Ceramic floor } \\
\text { Mortar plastering } \\
\text { Heavy concrete } \\
\end{array}$ \\
\hline Glass & Translucent $3 \mathrm{~mm}$ & Translucent $3 \mathrm{~mm}$ \\
\hline
\end{tabular}


According to ASHRAE, a value of 0.75 air changes of the total volume by hour was adopted. Table 2 shows building's occupancy schedule, for determining the higher and lower energy consumption periods.

\subsection{Fire Risk Analysis}

The simulation should consider the worst situation. Vertical proliferation of flames and smoke is faster, affecting upper floors quickly. Then, the fire is supposed to start in lower floors. The building's population can include people with disabilities, for example, wheelchair users.

\subsection{Energy Efficiency Simulation}

The simulation determines the energy consumption based on the construction materials, the best building orientation for reducing HVAC energy consumption, and the required LEED baseline building, which will serve as a standard comparative for green building certification.

A baseline building should be determined for each of the proposed models to serve as energy efficiency reference, considering the average consumption obtained from four different building rotations such as $0^{\circ}, 90^{\circ}, 180^{\circ}$ and $270^{\circ}$ (ASHRAE 90-1 2010, appendix G). Fig. 2 shows the influence of the two construction material lists on the energy consumption, it also shows that, the energy consumption is proportional to the window size. Figs. 3 and 4, respectively show the glass skin and $40 \%$ window size building consumption results considering different rotations and the most efficient materials (list 2 from Table 1), it also shows that, the $40 \%$ window size building is the most efficient. Fig. 5 shows the end user participation of each equipment type in $270^{\circ}$ orientation, although $90^{\circ}$ orientation shows a little better efficiency it is opposed to the street orientation. Fig. 6 shows that, in the glass skin building, the HVAC system consumes a bigger portion of the energy.

Different types of glasses were simulated. The
Table 2 Occupancy (\%).

\begin{tabular}{|c|c|c|c|}
\hline Schedule & $\begin{array}{l}\text { Monday to } \\
\text { Friday }\end{array}$ & Saturday & $\begin{array}{l}\text { Sunday \& } \\
\text { holydays }\end{array}$ \\
\hline $8: 00-9: 00$ & 25 & 0 & 0 \\
\hline 9:00-10:00 & 100 & 25 & 0 \\
\hline $10: 00-12: 00$ & 100 & 100 & 0 \\
\hline $12: 00-14: 00$ & 50 & 50 & 0 \\
\hline $14: 00-16: 00$ & 100 & 100 & 0 \\
\hline $16: 00-17: 00$ & 100 & 25 & 0 \\
\hline 17:00-18:00 & 100 & 0 & 0 \\
\hline 18:00-19:00 & 25 & 0 & 0 \\
\hline $\left.\begin{array}{l}400,000.00 \\
350,000,00\end{array}\right]$ & & & $\begin{array}{l}\text { Annual consumption } \\
\text { (kW/h) }\end{array}$ \\
\hline $300,000,00$ & & & - Heating \\
\hline $250,000,00$ & & & - Cooling \\
\hline $200,000,00$ & & & $\begin{array}{l}\text { ILightining } \\
\text { Eguipment }\end{array}$ \\
\hline $150,000.00$ & & & Eventlation \\
\hline $100,000,00$ & & & = Pumps \\
\hline $50,000,00$ & & & " Total \\
\hline
\end{tabular}

Fig. 2 Construction material influence over energy consumption.

G.S.—glass skin, $40 \%$ W.- $40 \%$ window size.

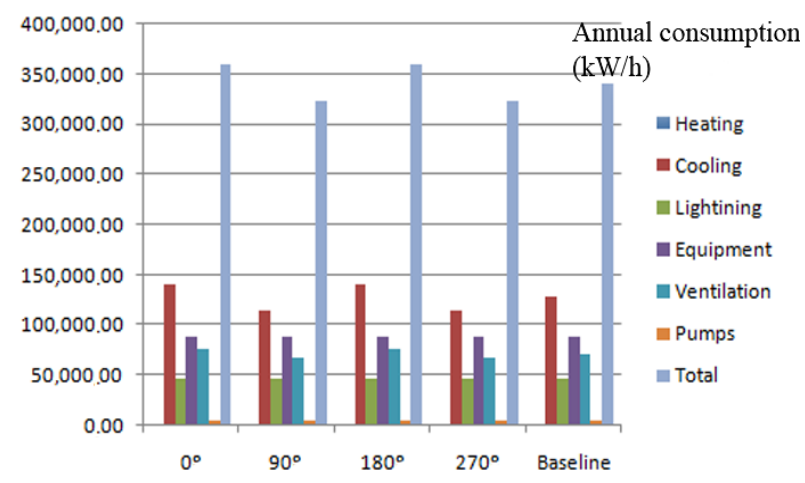

Fig. 3 Glass skin consumption results for different rotations.

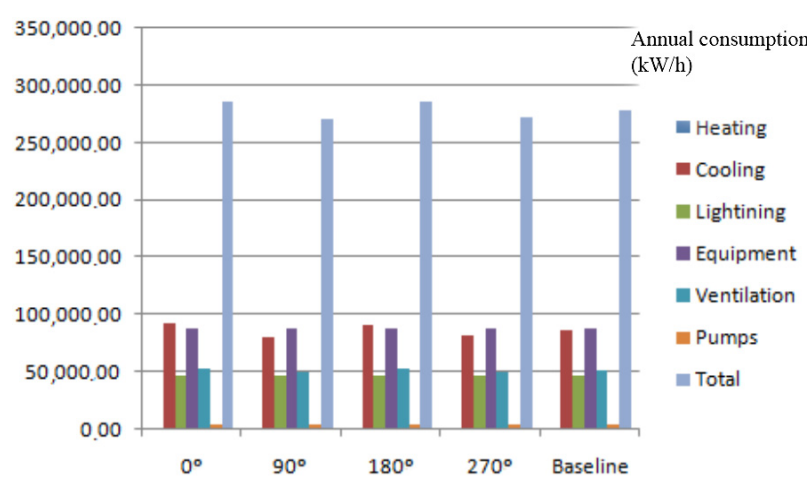

Fig. $4 \quad 40 \%$ window area consumption results for different rotations. 


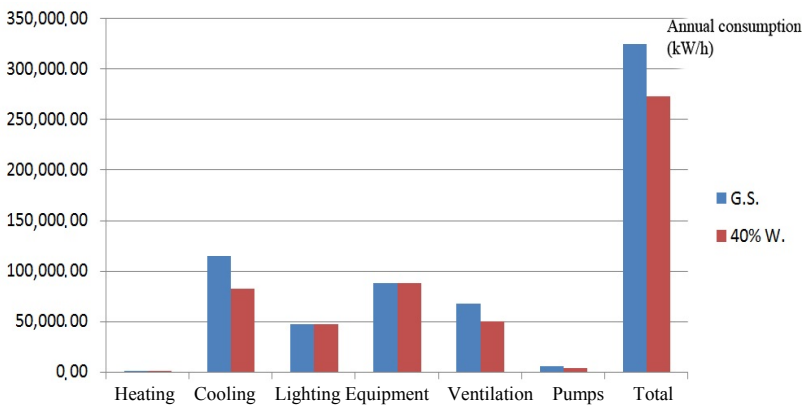

Fig. 5 End use participation by building type: glass skin vs. $40 \%$ window size $\left(90^{\circ}\right.$ orientation).

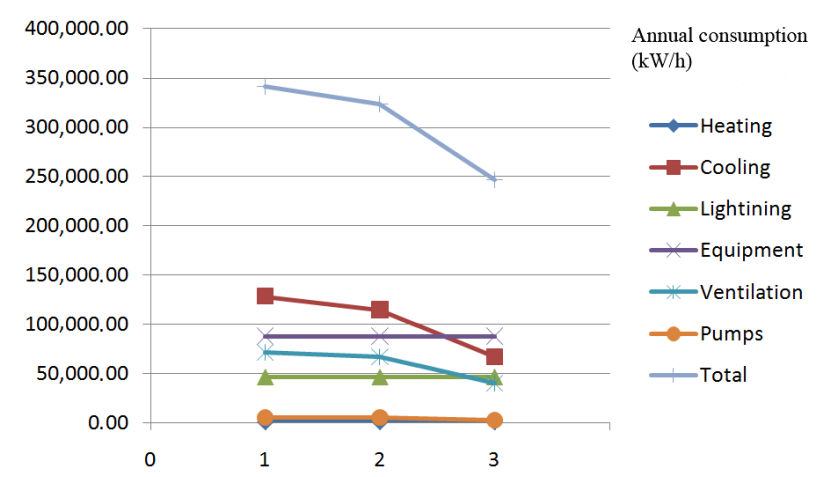

Fig. 6 Glass skin chart results.

simulation shown that, Galaxy Clearvision double glazing with an insulating gas interlayer of $13 \mathrm{~mm}$ and $6 \mathrm{~mm}$ clear window has a better efficiency. Figs. 6 and 7 show the simulation energy consumption results considering the glass skin and $40 \%$ window buildings with different structural modifications. Note that, the glass skin building will not consider sun blind shutter or awnings.

Applying blinds and efficient glazing in the $40 \%$ window building, the refrigeration energy consumption is reduced, but the energy for heating, ventilation and pump systems increases more, resulting in a final consumption of $4,516 \mathrm{~kW} / \mathrm{h}$, greater than the annual consumption applying only efficient glasses.

\subsection{Fire Simulation}

Pyrosim [12] was applied for fire simulation (only paper and wood are available as aggregated materials). The desired heat release rate curve followed the São Paulo's Decree $56819\left(700 \mathrm{MJ} / \mathrm{m}^{2}\right)$. For simulating ignition until the flashover, Pyrosim reference burner starts at $33,716 \mathrm{~W} / \mathrm{m}^{2}$, representing $0.2 \%$ of the total

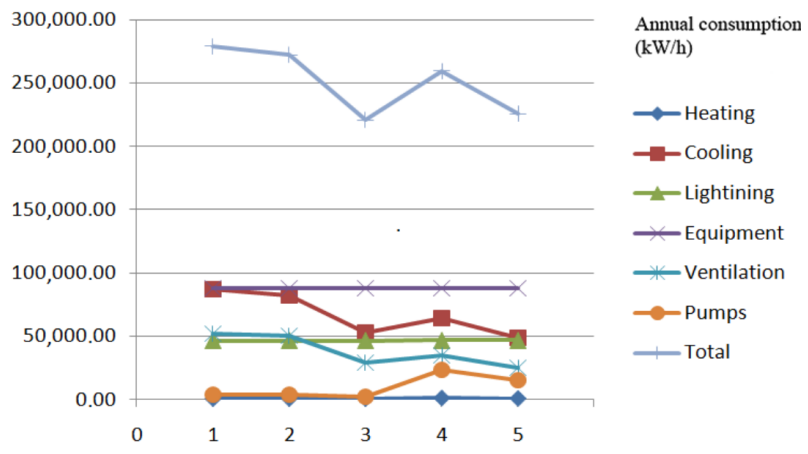

Fig. $7 \quad 40 \%$ window area chart results.

1 - baseline, 2-270 orientation, 3-efficient glazing (double glass Galaxy Clearvision $+13 \mathrm{~mm}$ air interlayer $(+6 \mathrm{~mm}$ clear window), 4-blinds and $270^{\circ}$ orientation, 5-three modifications simultaneously $\left(270^{\circ}\right.$ orientated, blinds and efficient glazing).

fire load (it has $0.50 \mathrm{~m}^{2}$ size and a heat release rate of $16,858 \mathrm{~kW})$. The mesh encloses $10 \mathrm{~m}$ beyond the building [13].

The fire starts in the middle of the 3rd floor's left room. Thermocouples are placed near the ceiling, in the middle and the corners (in both sides of each room windows). The glasses are set to disappear from simulation in each floor when a temperature of $250^{\circ} \mathrm{C}$ was reached in thermocouples near the windows, causing the outside air penetration.

Figs. 8a and 9a show the fire dynamics in the $40 \%$ window size and glass skin buildings; Figs. $8 \mathrm{~b}$ and $9 \mathrm{~b}$ present Pyrosim thermometer results, illustrating the temperature inside the 3rd floor where the fire is meant to start. Sprinklers are not mandatory in buildings lower than $30 \mathrm{~m}$ in Brazilian territory; Fig. 10 shows the temperature evolution considering an automatic sprinkler system.

Four evacuation sceneries were simulated applying Pathfinder [14], as follows:

Scenery 1: Only healthy people are in the building and only the emergency stairwell is an escape route;

Scenery 2: One wheelchair person is in 3rd floor (fire starting place), which must be evacuated by the elevator;

Scenery 3: Three persons with physical disabilities using the elevator, and healthy people being evacuated by the emergency stairwell; 


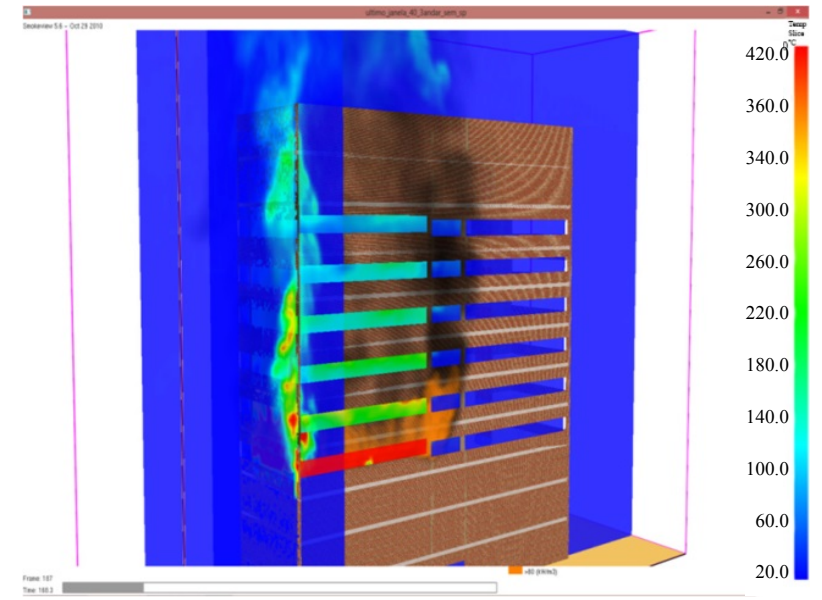

(a)

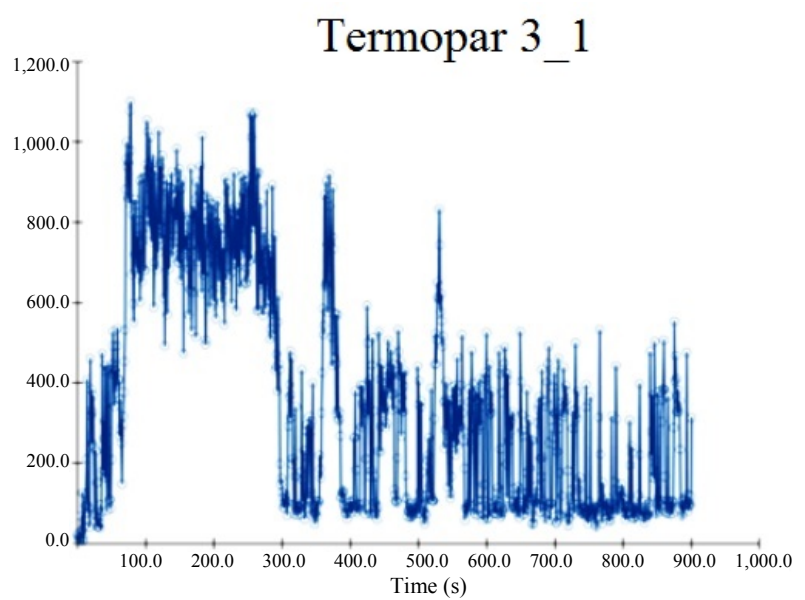

(b)

Fig. 8 (a) $40 \%$ window size building, (b) fire proliferation results.

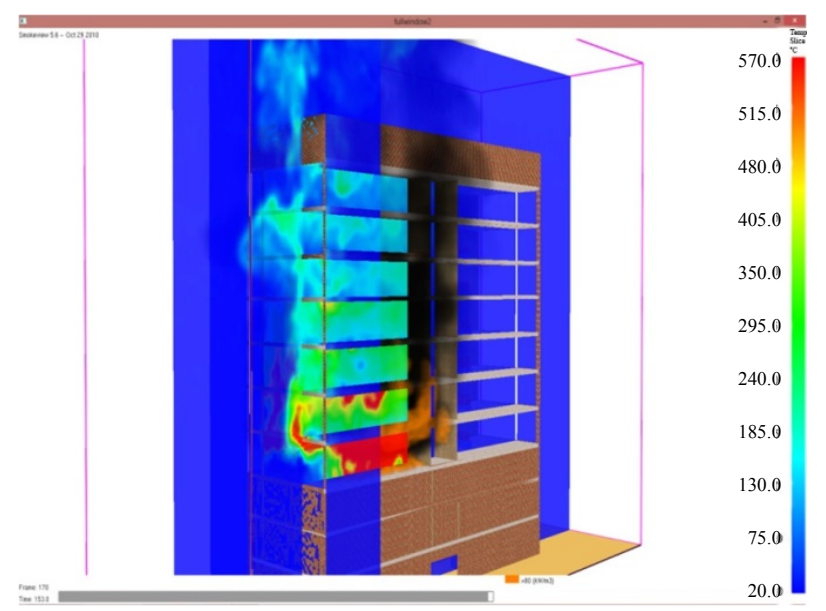

(a)

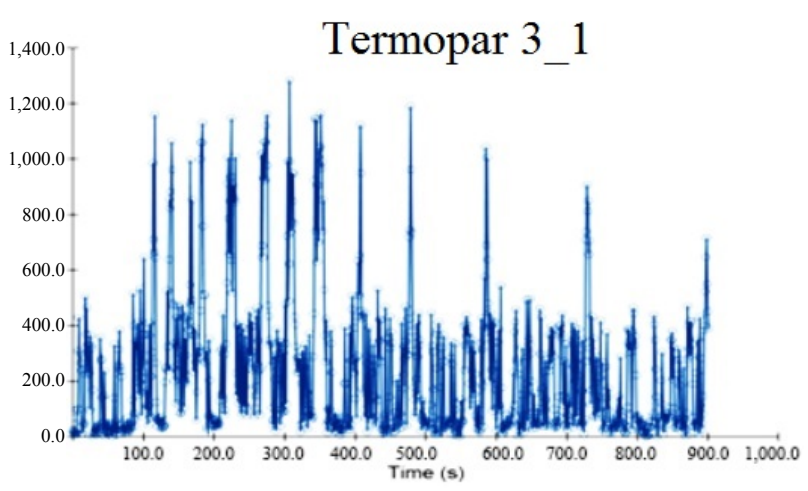

(b)

Fig. 9 (a) glass skin building, (b) fire proliferation results.

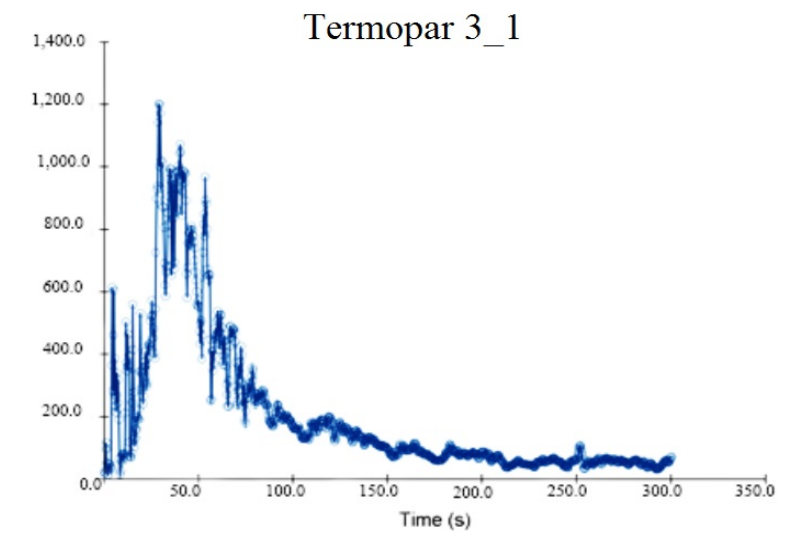

Fig. 10 Sprinkler time control results.

Scenery 4: Most people using the emergency stairwell, but also healthy and people with disabilities will use the elevator.
Table 3 shows the scenery results, also considering a 3 min pre-evacuation time [15-18]. Pathfinder and Pyrosim do not work together, although both programs belong to the same company. Thus, the evacuation simulator do not consider the effect of people been reached by fire.

\section{Results Analysis}

The energy simulation shows that, buildings with smaller window size are more efficient when applying common glasses. Applying special efficient glasses the energy savings is $27 \%$ in the glass skin building and $20 \%$ in the $40 \%$ window size. Note that, this modification greatly increases the energy efficiency in 
Table 3 Evacuation time results.

\begin{tabular}{|c|c|c|c|c|}
\hline Disability & Scenery 1 & Scenery 2 & Scenery 3 & Scenery 4 \\
\hline Wheelchair & - & 104.1 & 104.1 & 208.1 \\
\hline Lame & - & 67.2 & 173.9 & 360.6 \\
\hline Blind & - & 84.1 & 233.5 & 419.3 \\
\hline Total time & 155.3 & 159.5 & 233.5 & 419.3 \\
\hline \multicolumn{5}{|c|}{ Total evacuation time plus $3 \mathrm{~min}$ of pre movement } \\
\hline Disability & Scenery 1 & Scenery 2 & Scenery 3 & Scenery 4 \\
\hline Wheelchair & - & 284.1 & 284.1 & 388.1 \\
\hline Lame & - & 247.2 & 353.9 & 540.6 \\
\hline Blind & - & 264.1 & 413.5 & 599.3 \\
\hline Total time & 335.3 & 339.5 & 413.5 & 599.3 \\
\hline
\end{tabular}

the glass skin building, representing more credits for LEED green building certification. However, the total consumption is still higher in the glass skin building.

Figs. $8 b$ and $9 b$ show reduced fire proliferation rate in smaller window size buildings (small openings). Glass skin buildings have ventilation excess, producing fast fire proliferation to the upper floors. Other reason for this result is the thermal inertia characteristic of the concrete, granting a higher fire protection and reducing the spread of fire. The results of both simulations (considering buildings without sprinkler protection) show that, the alarm will be activated $80 \mathrm{~s}$ after the fire starts, with the third floor becoming hazardous $20 \mathrm{~s}$ after the alarm sounds. Mass casualties will happen, since the occupants of the other floors would spend from $336 \mathrm{~s}$ to $600 \mathrm{~s}$ for a full building evacuation (considering $3 \mathrm{~min}$. for pre-evacuation), because the fire spreads to the upper floors. Even ignoring the pre-evacuation time, the minimum evacuation time would be from $156 \mathrm{~s}$ to $420 \mathrm{~s}$, therefore building modifications are necessary to guaranteed the occupant safety (for example, fireproof stairs or implementing fire shelters). The floors below the fire source or close to the roof have a better protection for its occupants. In the $40 \%$ window size building, the floors affected by the fire were from 3rd to 9th, and in the glass skin, building floors from 3rd to 11 th were affected.

For performing modifications, the proposed methodology suggests their implementation in backward direction, until results are satisfactory. In this case, it is necessary to return to Step 5 (building materials), for example, considering isolated fireproof stairs, fire shelters, or fire resistant glasses. If results are still not satisfactory, then it is necessary to return to Step 4 (fire code), for example, considering sprinkles in both buildings. However, if results are still not satisfactory, then it is necessary to return to Step 1, for example, considering setback or balconies in the building plan (only possible in the $40 \%$ window building). In this case, modifications for the building location (Step 3) or building's population (Step 2) are not considered.

\section{Conclusions}

A methodology considering energy efficiency and fire safety was introduced. The methodology permits to analyze different building modifications (construction material types, different fire code requirements, etc.) for determining the better practices to be adopted. It will facilitate to observe the fire risks for each structural modification and new project. Fire simulations can be performed for determining the building's fire risk, its potential direct and indirect losses and whether the procedures adopted are enough to ensure the survival of the occupants.

Simulation programs are worth tools, helping to develop more efficient and more secure buildings, facilitating the integration of several factors, but any software can truly foresee people survive attitudes inside a building on fire, thus the simulation serves only as a small reference. Pyrosim lacks of a fully fire load library, only paper and wood were tested as fire aggregated loads. It is highly recommended to simulate the full aggregated fire loads that could be found inside a building to get a better understand of the fire risks.

Different opening sizes directly impact the energy efficiency and fire spread in buildings, although special glazing grants better energy savings, it may 
become a rescue barrier for firefighters. The $40 \%$ window building also permits more structural changes, such as applying setbacks or balconies, therefore, it can be more secure than the glass skin building.

The green building fire risk analysis is a new study field. More studies should be conducted for integrating fire risk and energy efficiency.

\section{References}

[1] Escrivã, E. G., Santamaría, O., and Mugarra, L. F. 2012. "Continuous Assestment of Energy Efficiency in Commercial Buildings Using Energy Ratings Factors." Elsevier Energy and Buildings 49 (June): 78-84.

[2] Salman, A., Wade, A. C., Darren, O., and Irtishad, A. 2011. "Building Information Modeling for Sustainable Design and LEED $^{\circledR}$ Rating Analysis.” Elsevier Automation in Construction 20 (2): 217-24.

[3] USGBC (U.S. Green Building Council). 2009. "LEED 2009 for New Construction and Major Renovations." USGBC.

[4] GBCI (Green Business Certification Inc.). 2012. "LEED Certification Policy Manual." GBCI.

[5] Dall'O, G., Speccher, A., and Bruni, E. 2012, “The Green Energy Audit, a New Procedure for the Sustainable Auditing of Existing Buildings Integrated with the LEED Protocols." Elsevier Sustainable Cities and Society 3 (July): 54-65.

[6] Meacham, B., Poole, B., Echeverria, J., and Cheng, R. 2012. "Fire Safety Challenges of Green Buildings." In The Fire Protection Research Foundation, Springer, MA: Worcester Polytechnic Institute.

[7] Meacham, B. 2012. "Fire Safety Challenges of Green Building Presentation." Presented at the Fire Safety and Sustainable Building Symposium, Chicago, USA.

[8] Tidwell, J., and Murphy, J. J. 2010. Bridging the Gap: Fire Safety and Green Buildings. A Fire and Building
Safety Guide to Green Construction. Quincy: National Association of State Fire Marshals.

[9] Patterson, M. G. 1996. What is Energy Efficiency? Concepts, Indicators and Method. Palmerston North: Elsevier Sci. Ltd.

[10] São Paulo's Fire Department. 2011. "São Paulo State Law 56819." São Paulo's Fire Department. Accessed September $10,2015$. http://www.ccb.policiamilitar.sp.gov.br/credenciamento/d ownloads/Decreto_Estadual_56819.pdf.

[11] ASHRAE (American Society of Heating, Refrigerating and Air-Conditioning Engineers) 90-1. 2010. "Energy Standard for Buildings Except Low-Rise Residential Buildings." ASHRAE.

[12] Thunderheard Engineering. 2013. "Pyrosim User Manual." Thunderheard Engineering. Accessed September 10, 2015. http://www.thunderheadeng.com.

[13] Mazzoni, F. 2010. Fire Simulation: A Study of the Cacique Bldg. Porto Alegre: UFRGS (Universidade Federal do Rio Grande do Sul).

[14] Thunderheard Engineering. 2013. "Pathfinder User Manual." Thunderheard Engineering. Accessed September 10, 2015. http://www.thunderheadeng.com.

[15] Tong, D., and Canter, D. 1985. "The Decision to Evacuate: A Study of the Motivations Which Contribute to Evacuation in the Event of Fire." Fire Safety Journal 9 (3): 257-65.

[16] Kobes, M., Helsloot, I., Vries, B., and de Post, J. G. 2010. "Building Safety and Human Behavior in Fire: A Literature Review." Elsevier Fire Safety Journal 45 (1): 1-11.

[17] Proulx, G. 1995. "Evacuation Time and Movement in Apartment Buildings." Elsevier Fire Safety Journal 24 (3): $229-46$.

[18] Chow, W. K., and Chow, C. L. 2005. "Evacuation with Smoke Control for Atria in Green and Sustainable Buildings." Elsevier Building and Environment 40 (2): 195-200. 